\title{
Recommended Frit Composition for Initial Sludge Batch 5 Processing at the Defense Waste Processing Facility
}

K.M. Fox

T.B. Edwards

D.K. Peeler

June 2008

E\&CPT Research Programs

Savannah River National Laboratory Aiken, SC 29808 
WSRC-STI-2008-00338

Revision 0

\section{DISCLAIMER}

This report was prepared by Washington Savannah River Company (WSRC) for the United States Department of Energy under Contract No. DE-AC09-96SR18500 and is an account of work performed under that contract. Neither the United States Department of Energy, nor WSRC, nor any of their employees makes any warranty, expressed or implied, or assumes any legal liability or responsibility for the accuracy, completeness, or usefulness, of any information, apparatus, or product or process disclosed herein or represents that its use will not infringe privately owned rights. Reference herein to any specific commercial product, process, or service by trademark, name, manufacturer or otherwise does not necessarily constitute or imply endorsement, recommendation, or favoring of same by WSRC or by the United States Government or any agency thereof. The views and opinions of the authors expressed herein do not necessarily state or reflect those of the United States Government or any agency thereof.

\section{Printed in the United States of America \\ Prepared For U.S. Department of Energy}

The Savannah River National Laboratory is operated for the U.S. Department of Energy by Washington Savannah River Company. 
Keywords: high level waste, frit, DWPF

Retention: permanent

\section{Recommended Frit Composition for Initial Sludge Batch 5 Processing at the Defense Waste Processing Facility}

K.M. Fox

T.B. Edwards

D.K. Peeler

June 2008

E\&CPT Research Programs

Savannah River National Laboratory Aiken, SC 29808 


\section{REVIEWS AND APPROVALS}

\section{AUTHORS:}

K.M. Fox, Process Engineering Technology

Date

T.B. Edwards, Statistical Consulting

Date

D.K. Peeler, Process Engineering Technology

Date

TECHNICAL REVIEWER:

F.C. Raszewski, Process Engineering Technology

Date

\section{APPROVERS:}

C.C. Herman, Manager, Process Technology Programs

Date

J.C. Griffin, Manager, E\&CPT Research Programs

Date

J.E. Occhipinti, Manager, Waste Solidification Engineering

Date 


\section{EXECUTIVE SUMMARY}

The Savannah River National Laboratory (SRNL) Frit Development Team recommends that the Defense Waste Processing Facility (DWPF) utilize Frit 418 for initial processing of high level waste (HLW) Sludge Batch 5 (SB5). The extended SB5 preparation time and need for DWPF feed have necessitated the use of a frit that is already included on the DWPF procurement specification. Frit 418 has been used previously in vitrification of Sludge Batches 3 and 4 . Paper study assessments predict that Frit 418 will form an acceptable glass when combined with SB5 over a range of waste loadings (WLs), typically $30-41 \%$ based on nominal projected SB5 compositions. Frit 418 has a relatively high degree of robustness with regard to variation in the projected SB5 composition, particularly when the $\mathrm{Na}_{2} \mathrm{O}$ concentration is varied. The acceptability (chemical durability) and model applicability of the Frit 418-SB5 system will be verified experimentally through a variability study, to be documented separately. Frit 418 has not been designed to provide an optimal melt rate with SB5, but is recommended for initial processing of SB5 until experimental testing to optimize a frit composition for melt rate can be completed. Melt rate performance can not be predicted at this time and must be determined experimentally. Note that melt rate testing may either identify an improved frit for SB5 processing (one which produces an acceptable glass at a faster rate than Frit 418) or confirm that Frit 418 is the best option. 


\section{TABLE OF CONTENTS}

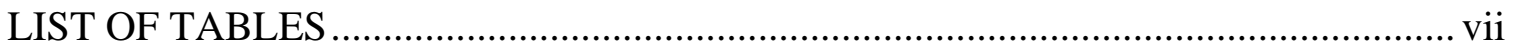

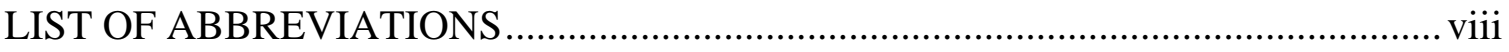

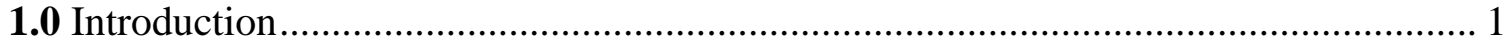

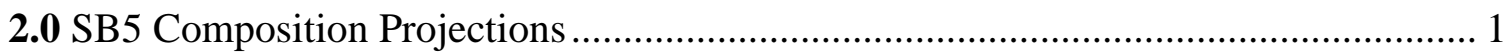

3.0 Assessments of Frit 418 with the Nominal SB5 Compositions .................................. 5

4.0 Variation Stage Assessment of Frit 418 Bounding Potential SB5 Compositions ........ 6

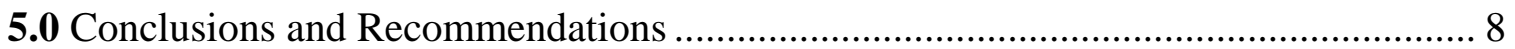

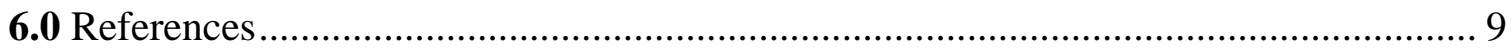


WSRC-STI-2008-00338

Revision 0

\section{LIST OF TABLES}

Table 2-1. Composition Projections (wt\% Calcined Oxides) of the Tank 40 Heel and Tank 51 Provided by LWO, as well as a $3 \mathrm{wt} \% \mathrm{Na}_{2} \mathrm{O}$ addition to the Tank 40 Heel Projection........... 2

Table 2-2. Composition Projections (wt\% Calcined Oxides) of the Tank 40 Heel and Tank 51 Developed by SRNL, as well as a $3 \mathrm{wt} \% \mathrm{Na}_{2} \mathrm{O}$ addition to the Tank 40 Heel Projection....... 3

Table 2-3. Potential Compositions of the SB5 Blend Using the LWO and SRNL Projections at Two Blend Ratios, With and Without Caustic Addition to Tank 40.................................... 4

Table 2-4. Potential Compositions of the SB5 Blend Using the LWO and SRNL Projections at Two Blend Ratios, With and Without Caustic Addition, With the ARP Stream Added......... 5

Table 3-1. MAR Assessment Results for the Nominal SB5 Compositions with Frit 418............. 6

Table 4-1. Concentration Ranges for Individual Components in the SB5 Composition as Defined for the Variation Stage Assessment. .................................................................................... 7

Table 4-2. Portion of the Variation Stage MAR Assessment Results for SB5 with Frit 418......... 8 


\section{LIST OF ABBREVIATIONS}

$\begin{array}{ll}\text { ARP } & \text { Actinide Removal Process } \\ \text { DWPF } & \text { Defense Waste Processing Facility } \\ \text { EVs } & \text { Extreme Vertices } \\ \text { HLW } & \text { High Level Waste } \\ \text { Homg } & \text { Homogeneity } \\ \text { lowv } & \text { low viscosity } \\ \text { LWO } & \text { Liquid Waste Organization } \\ \text { MAR } & \text { Measurement Acceptability Region } \\ \text { Neph } & \text { Nepheline } \\ \text { PCCS } & \text { Product Composition Control System } \\ \text { SB4 } & \text { Sludge Batch } 4 \\ \text { SB5 } & \text { Sludge Batch } 5 \\ \text { SRNL } & \text { Savannah River National Laboratory } \\ T_{L} & \text { Liquidus Temperature } \\ \text { WL } & \text { Waste Loading } \\ \text { WSRC } & \text { Washington Savannah River Company }\end{array}$


WSRC-STI-2008-00338

Revision 0

\subsection{Introduction}

The objective of this task was to identify a frit for vitrification of high level waste (HLW) Sludge Batch 5 (SB5) at the Defense Waste Processing Facility (DWPF) that:

- is currently listed on the DWPF procurement specification to reduce the time necessary for procurement (due to the short time period available for frit development work),

- will form acceptable (in terms of repository requirements and DWPF processing constraints) glasses with SB5,

- is relatively insensitive (based on projected operating windows) to the uncertainty in the SB5 composition projections.

These objectives were met by:

- identifying the best available composition projections for SB5,

- adding any necessary corrections to the composition projections to account for planned caustic additions and blending operations,

- evaluating the operating windows (the range of waste loadings where acceptable glasses are predicted) projected for Frit 418 with these nominal SB5 projections,

- evaluating the operating windows projected for Frit 418 with variation applied to a bounding SB5 projection.

Each of these steps will be described in further detail in the following sections. This work is performed in response to Technical Task Request HLW-DWPF-TTR-2007-0007 ${ }^{1}$ following Task Technical and Quality Assurance Plan WSRC-STI-2006-00321. ${ }^{2}$

\subsection{SB5 Composition Projections}

A series of SB5 composition projections has been received from the Liquid Waste Organization (LWO). ${ }^{a}$ SRNL also developed projections ${ }^{\mathrm{b}}$ for SB5 using a model-based approach. ${ }^{\mathrm{c}}$ The LWO and SRNL projections included the Tank 40 heel remaining at the end of Sludge Batch 4 (SB4) processing, the Tank 51 SB5 batch prior to the transfer to Tank 40, and the SB5 blend in Tank 40 after the transfer from Tank 51. None of the projections accounted for the planned addition of caustic to Tank 40 to support SB4 processing. The SB5 blend projections did not account for the addition of the Actinide Removal Process (ARP) stream to SB5 at DWPF. In addition, the final blend ratio of the Tank 51 SB5 batch with the Tank 40 heel to constitute the SB5 blend is uncertain due to the estimated sludge usage over the next four months of processing.

To account for these additions and the blending uncertainties, only the LWO and SRNL projected compositions of the Tank 40 heel and the Tank 51 SB5 batch were used to support the frit recommendation. First, projections of the Tank 40 heel composition based on the planned addition of caustic were developed by adding $3 \mathrm{wt} \% \mathrm{Na}_{2} \mathrm{O}$ to the original Tank 40 heel projections and renormalizing the composition to $100 \%$. The composition projections provided by LWO, along with the $3 \mathrm{wt} \% \mathrm{Na}_{2} \mathrm{O}$ addition to the Tank 40 heel are listed in Table 2-1.

\footnotetext{
${ }^{a}$ The most recent SB5 composition projections (those used in this study) were received from LWO via email from D. D. Larsen on June 5, 2008. Washing data used to calculate a $\mathrm{SO}_{4}{ }^{2-}$ concentration were included in a spreadsheet attached to the email, titled 'SB4-5_060408_For Variability Study Comparison.xls.xlsm'. See WSRC-NB-2007-00003 for further detail.

b The composition projections developed by SRNL and used in this study were received via email from A. S. Choi on June 12, 2008. See WSRC-NB-2007-00003 for further detail.

${ }^{c}$ For further information on the SRNL model-based approach, see Choi, A. S., "Aluminum Dissolution Flowsheet Modeling in Support of SB5 Frit Development,” U.S. Department of Energy Report WSRC-STI-2008-00001, Revision 0, Washington Savannah River Company, Aiken, SC (2008).
} 
Table 2-1. Composition Projections (wt\% Calcined Oxides) of the Tank 40 Heel and Tank 51 Provided by $L W O$, as well as a 3 wt \% $\mathrm{Na}_{2} \mathrm{O}$ addition to the Tank 40 Heel Projection.

\begin{tabular}{|c|c|c|c|}
\hline Oxide & Tank 40 Heel & $\begin{array}{c}\text { Tank } 40 \text { Heel plus } \\
3 \mathrm{wt} \% \mathrm{Na}_{2} \mathrm{O} \\
\end{array}$ & $\begin{array}{c}\text { Tank 51 } \\
\text { (SB5 Batch) } \\
\end{array}$ \\
\hline $\mathrm{Al}_{2} \mathrm{O}_{3}$ & 26.960 & 26.013 & 19.673 \\
\hline $\mathrm{BaO}$ & 0.077 & 0.075 & 0.000 \\
\hline $\mathrm{CaO}$ & 2.969 & 2.865 & 2.258 \\
\hline $\mathrm{Ce}_{2} \mathrm{O}_{3}$ & 0.070 & 0.067 & 0.000 \\
\hline $\mathrm{Cr}_{2} \mathrm{O}_{3}$ & 0.174 & 0.168 & 0.000 \\
\hline $\mathrm{CuO}$ & 0.062 & 0.060 & 0.000 \\
\hline $\mathrm{Fe}_{2} \mathrm{O}_{3}$ & 30.821 & 29.737 & 27.594 \\
\hline $\mathrm{K}_{2} \mathrm{O}$ & 0.000 & 0.000 & 0.036 \\
\hline $\mathrm{La}_{2} \mathrm{O}_{3}$ & 0.058 & 0.056 & 0.000 \\
\hline $\mathrm{MgO}$ & 2.927 & 2.824 & 1.190 \\
\hline $\mathrm{MnO}$ & 6.184 & 5.967 & 5.828 \\
\hline $\mathrm{Na}_{2} \mathrm{O}$ & 14.649 & 17.649 & 29.494 \\
\hline $\mathrm{NiO}$ & 1.716 & 1.656 & 3.512 \\
\hline $\mathrm{PbO}$ & 0.064 & 0.062 & 0.000 \\
\hline $\mathrm{SO}_{4}{ }^{2-}$ & 0.831 & 0.802 & 0.373 \\
\hline $\mathrm{SiO}_{2}$ & 2.906 & 2.804 & 2.217 \\
\hline $\mathrm{ThO}_{2}$ & 0.000 & 0.000 & 0.000 \\
\hline $\mathrm{TiO}_{2}$ & 0.050 & 0.048 & 0.000 \\
\hline $\mathrm{U}_{3} \mathrm{O}_{8}$ & 9.401 & 9.071 & 7.825 \\
\hline $\mathrm{ZnO}$ & 0.000 & 0.000 & 0.000 \\
\hline $\mathrm{ZrO}_{2}$ & 0.080 & 0.078 & 0.000 \\
\hline
\end{tabular}

The composition projections developed by SRNL, along with the $3 \mathrm{wt} \% \mathrm{Na}_{2} \mathrm{O}$ addition to the Tank 40 heel are listed in Table 2-2. 
WSRC-STI-2008-00338

Revision 0

Table 2-2. Composition Projections (wt\% Calcined Oxides) of the Tank 40 Heel and Tank 51 Developed by SRNL, as well as a $3 \mathrm{wt} \% \mathrm{Na}_{2} \mathrm{O}$ addition to the Tank 40 Heel Projection.

\begin{tabular}{|c|c|c|c|}
\hline Oxide & Tank 40 Heel & $\begin{array}{c}\text { Tank } 40 \text { Heel plus } \\
3 \text { wt \% } \mathrm{Na}_{2} \mathrm{O}\end{array}$ & $\begin{array}{c}\text { Tank 51 } \\
\text { (SB5 Batch) }\end{array}$ \\
\hline $\mathrm{Ag}_{2} \mathrm{O}$ & 0.009 & 0.009 & 0.004 \\
\hline $\mathrm{Al}_{2} \mathrm{O}_{3}$ & 25.976 & 25.040 & 20.874 \\
\hline $\mathrm{BaO}$ & 0.078 & 0.075 & 0.164 \\
\hline $\mathrm{CaO}$ & 2.868 & 2.764 & 2.366 \\
\hline $\mathrm{CdO}$ & 0.322 & 0.310 & 0.027 \\
\hline $\mathrm{Ce}_{2} \mathrm{O}_{3}$ & 0.068 & 0.066 & 0.000 \\
\hline $\mathrm{Cr}_{2} \mathrm{O}_{3}$ & 0.150 & 0.145 & 0.088 \\
\hline $\mathrm{CuO}$ & 0.058 & 0.055 & 0.015 \\
\hline $\mathrm{Fe}_{2} \mathrm{O}_{3}$ & 33.075 & 31.883 & 28.881 \\
\hline $\mathrm{Gd}_{2} \mathrm{O}_{3}$ & 0.015 & 0.014 & 0.026 \\
\hline $\mathrm{K}_{2} \mathrm{O}$ & 0.226 & 0.218 & 0.101 \\
\hline $\mathrm{La}_{2} \mathrm{O}_{3}$ & 0.051 & 0.049 & 0.000 \\
\hline $\mathrm{Li}_{2} \mathrm{O}$ & 0.041 & 0.040 & 0.005 \\
\hline $\mathrm{MgO}$ & 2.820 & 2.718 & 1.253 \\
\hline $\mathrm{MnO}$ & 5.969 & 5.754 & 6.106 \\
\hline $\mathrm{Na}_{2} \mathrm{O}$ & 12.739 & 15.739 & 25.090 \\
\hline $\mathrm{NiO}$ & 1.654 & 1.594 & 3.680 \\
\hline $\mathrm{P}_{2} \mathrm{O}_{5}$ & 0.989 & 0.954 & 0.125 \\
\hline $\mathrm{PbO}$ & 0.039 & 0.038 & 0.004 \\
\hline $\mathrm{PdO}$ & 0.001 & 0.001 & 0.001 \\
\hline $\mathrm{PuO}_{2}$ & 0.000 & 0.000 & 0.010 \\
\hline $\mathrm{Rh}_{2} \mathrm{O}_{3}$ & 0.015 & 0.015 & 0.034 \\
\hline $\mathrm{RuO}_{2}$ & 0.060 & 0.058 & 0.171 \\
\hline $\mathrm{SO}_{4}{ }^{2-}$ & 0.899 & 0.866 & 0.539 \\
\hline $\mathrm{SiO}_{2}$ & 2.795 & 2.694 & 2.071 \\
\hline $\mathrm{SrO}$ & 0.040 & 0.039 & 0.080 \\
\hline $\mathrm{ThO}_{2}$ & 0.000 & 0.000 & 0.000 \\
\hline $\mathrm{TiO}_{2}$ & 0.040 & 0.039 & 0.000 \\
\hline $\mathrm{U}_{3} \mathrm{O}_{8}$ & 9.068 & 8.742 & 8.191 \\
\hline $\mathrm{ZnO}$ & 0.005 & 0.005 & 0.012 \\
\hline $\mathrm{ZrO}_{2}$ & 0.079 & 0.076 & 0.171 \\
\hline
\end{tabular}

Second, two possible blending ratios were considered for constitution of the SB5 blend. ${ }^{\text {a }}$ Mass ratios of 25:75 and 30:70 (Tank 40 to Tank 51) were used in blending the Tank 40 heel and Tank 51 SB5 batch compositions, both with and without the caustic addition, using both the LWO and SRNL projections. These factors resulted in eight potential compositions for SB5, as listed in Table 2-3.

\footnotetext{
${ }^{\mathrm{a}}$ The final blend ratio is dependent mainly on the rate of SB4 processing, in DWPF.
} 
Table 2-3. Potential Compositions of the SB5 Blend Using the LWO and SRNL Projections at Two Blend Ratios, With and Without Caustic Addition to Tank 40.

\begin{tabular}{|c|c|c|c|c|c|c|c|c|}
\hline $\begin{array}{c}\text { Tank } 40 \\
\text { Source }\end{array}$ & LWO & LWO & $\begin{array}{c}\text { LWO } \\
+3 \mathrm{wt} \% \mathrm{Na}_{2} \mathrm{O} \\
\end{array}$ & $\begin{array}{c}\text { LWO } \\
+3 \mathrm{wt} \% \mathrm{Na}_{2} \mathrm{O} \\
\end{array}$ & SRNL & SRNL & $\begin{array}{c}\text { SRNL } \\
+3 \mathrm{wt} \% \mathrm{Na}_{2} \mathrm{O}\end{array}$ & $\begin{array}{c}\text { SRNL } \\
+3 \mathrm{wt} \% \mathrm{Na}_{2} \mathrm{O} \\
\end{array}$ \\
\hline $\begin{array}{c}\text { Tank } 40 \\
\text { Mass Ratio }\end{array}$ & 25 & 30 & 25 & 30 & 25 & 30 & 25 & 30 \\
\hline $\begin{array}{c}\text { Tank } 51 \\
\text { Source }\end{array}$ & LWO & LWO & LWO & LWO & SRNL & SRNL & SRNL & SRNL \\
\hline $\begin{array}{c}\text { Tank } 51 \\
\text { Mass Ratio }\end{array}$ & 75 & 70 & 75 & 70 & 75 & 70 & 75 & 70 \\
\hline Sludge ID & BS-01 & BS-02 & BS-03 & BS-04 & BS-05 & BS-06 & BS-07 & BS-08 \\
\hline $\mathrm{Ag}_{2} \mathrm{O}$ & 0.000 & 0.000 & 0.000 & 0.000 & 0.005 & 0.005 & 0.005 & 0.005 \\
\hline $\mathrm{Al}_{2} \mathrm{O}_{3}$ & 21.495 & 21.859 & 21.258 & 21.575 & 22.149 & 22.405 & 21.915 & 22.124 \\
\hline $\mathrm{BaO}$ & 0.019 & 0.023 & 0.019 & 0.022 & 0.142 & 0.138 & 0.142 & 0.137 \\
\hline $\mathrm{CaO}$ & 2.436 & 2.472 & 2.410 & 2.440 & 2.491 & 2.516 & 2.465 & 2.485 \\
\hline $\mathrm{CdO}$ & 0.000 & 0.000 & 0.000 & 0.000 & 0.101 & 0.116 & 0.098 & 0.112 \\
\hline $\mathrm{Ce}_{2} \mathrm{O}_{3}$ & 0.017 & 0.021 & 0.017 & 0.020 & 0.017 & 0.020 & 0.016 & 0.020 \\
\hline $\mathrm{Cr}_{2} \mathrm{O}_{3}$ & 0.043 & 0.052 & 0.042 & 0.050 & 0.103 & 0.106 & 0.102 & 0.105 \\
\hline $\mathrm{CuO}$ & 0.016 & 0.019 & 0.015 & 0.018 & 0.026 & 0.028 & 0.025 & 0.027 \\
\hline $\mathrm{Fe}_{2} \mathrm{O}_{3}$ & 28.400 & 28.562 & 28.130 & 28.237 & 29.930 & 30.139 & 29.632 & 29.782 \\
\hline $\mathrm{Gd}_{2} \mathrm{O}_{3}$ & 0.000 & 0.000 & 0.000 & 0.000 & 0.023 & 0.023 & 0.023 & 0.023 \\
\hline $\mathrm{K}_{2} \mathrm{O}$ & 0.027 & 0.025 & 0.027 & 0.025 & 0.132 & 0.138 & 0.130 & 0.136 \\
\hline $\mathrm{La}_{2} \mathrm{O}_{3}$ & 0.015 & 0.017 & 0.014 & 0.017 & 0.013 & 0.015 & 0.012 & 0.015 \\
\hline $\mathrm{Li}_{2} \mathrm{O}$ & 0.000 & 0.000 & 0.000 & 0.000 & 0.014 & 0.016 & 0.013 & 0.015 \\
\hline $\mathrm{MgO}$ & 1.624 & 1.711 & 1.598 & 1.680 & 1.645 & 1.723 & 1.620 & 1.693 \\
\hline $\mathrm{MnO}$ & 5.917 & 5.935 & 5.863 & 5.870 & 6.072 & 6.065 & 6.018 & 6.000 \\
\hline $\mathrm{Na}_{2} \mathrm{O}$ & 25.783 & 25.040 & 26.533 & 25.940 & 22.003 & 21.385 & 22.753 & 22.285 \\
\hline $\mathrm{NiO}$ & 3.063 & 2.973 & 3.048 & 2.955 & 3.174 & 3.072 & 3.159 & 3.054 \\
\hline $\mathrm{P}_{2} \mathrm{O}_{5}$ & 0.000 & 0.000 & 0.000 & 0.000 & 0.341 & 0.384 & 0.332 & 0.374 \\
\hline $\mathrm{PbO}$ & 0.016 & 0.019 & 0.015 & 0.019 & 0.013 & 0.015 & 0.013 & 0.014 \\
\hline $\mathrm{PdO}$ & 0.000 & 0.000 & 0.000 & 0.000 & 0.001 & 0.001 & 0.001 & 0.001 \\
\hline $\mathrm{Pr}_{2} \mathrm{O}_{3}$ & 0.000 & 0.000 & 0.000 & 0.000 & 0.000 & 0.000 & 0.000 & 0.000 \\
\hline $\mathrm{PuO}_{2}$ & 0.000 & 0.000 & 0.000 & 0.000 & 0.008 & 0.007 & 0.008 & 0.007 \\
\hline $\mathrm{Rh}_{2} \mathrm{O}_{3}$ & 0.000 & 0.000 & 0.000 & 0.000 & 0.030 & 0.029 & 0.029 & 0.028 \\
\hline $\mathrm{RuO}_{2}$ & 0.000 & 0.000 & 0.000 & 0.000 & 0.143 & 0.137 & 0.142 & 0.137 \\
\hline $\mathrm{SO}_{4}{ }^{2-}$ & 0.487 & 0.510 & 0.480 & 0.502 & 0.629 & 0.647 & 0.621 & 0.637 \\
\hline $\mathrm{SiO}_{2}$ & 2.389 & 2.424 & 2.364 & 2.393 & 2.252 & 2.288 & 2.227 & 2.258 \\
\hline $\mathrm{SrO}$ & 0.000 & 0.000 & 0.000 & 0.000 & 0.070 & 0.068 & 0.069 & 0.067 \\
\hline $\mathrm{ThO}_{2}$ & 0.000 & 0.000 & 0.000 & 0.000 & 0.000 & 0.000 & 0.000 & 0.000 \\
\hline $\mathrm{TiO}_{2}$ & 0.012 & 0.015 & 0.012 & 0.014 & 0.010 & 0.012 & 0.010 & 0.012 \\
\hline $\mathrm{U}_{3} \mathrm{O}_{8}$ & 8.219 & 8.298 & 8.137 & 8.199 & 8.410 & 8.454 & 8.329 & 8.356 \\
\hline $\mathrm{ZnO}$ & 0.000 & 0.000 & 0.000 & 0.000 & 0.010 & 0.010 & 0.010 & 0.010 \\
\hline $\mathrm{ZrO}_{2}$ & 0.020 & 0.024 & 0.019 & 0.023 & 0.148 & 0.144 & 0.148 & 0.143 \\
\hline
\end{tabular}

Third, the addition of the ARP stream ${ }^{\mathrm{a}}$ was included for each of the above compositions, resulting in eight more potential compositions for SB5 as listed in Table 2-4.

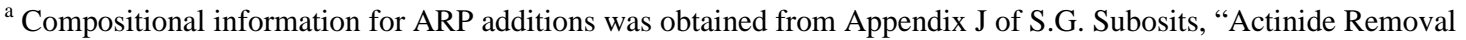
Process Material Balance Calculation with Low Curie Salt Feed,” X-CLC-S-00113, Rev. 0, September 24, 2004.
} 
Table 2-4. Potential Compositions of the SB5 Blend Using the LWO and SRNL Projections at Two Blend Ratios, With and Without Caustic Addition, With the ARP Stream Added.

\begin{tabular}{|c|c|c|c|c|c|c|c|c|}
\hline $\begin{array}{c}\text { Tank } 40 \\
\text { Source } \\
\end{array}$ & LWO & LWO & $\begin{array}{c}\text { LWO } \\
+3 \mathrm{wt} \% \mathrm{Na}_{2} \mathrm{O} \\
\end{array}$ & $\begin{array}{c}\text { LWO } \\
+3 \mathrm{wt} \% \mathrm{Na}_{2} \mathrm{O} \\
\end{array}$ & SRNL & SRNL & $\begin{array}{c}\text { SRNL } \\
+3 \mathrm{wt} \% \mathrm{Na}_{2} \mathrm{O} \\
\end{array}$ & $\begin{array}{c}\text { SRNL } \\
+3 \mathrm{wt} \% \mathrm{Na}_{2} \mathrm{O} \\
\end{array}$ \\
\hline $\begin{array}{c}\text { Tank } 40 \\
\text { Mass Ratio }\end{array}$ & 25 & 30 & 25 & 30 & 25 & 30 & 25 & 30 \\
\hline $\begin{array}{c}\text { Tank } 51 \\
\text { Source }\end{array}$ & LWO & LWO & LWO & LWO & SRNL & SRNL & SRNL & SRNL \\
\hline $\begin{array}{c}\text { Tank } 51 \\
\text { Mass Ratio }\end{array}$ & 75 & 70 & 75 & 70 & 75 & 70 & 75 & 70 \\
\hline Sludge ID & BS-09 & BS-10 & BS-11 & BS-12 & BS-13 & BS-14 & BS-15 & BS-16 \\
\hline $\mathrm{Ag}_{2} \mathrm{O}$ & 0.003 & 0.003 & 0.003 & 0.003 & 0.007 & 0.008 & 0.007 & 0.008 \\
\hline $\mathrm{Al}_{2} \mathrm{O}_{3}$ & 20.741 & 21.087 & 20.516 & 20.817 & 21.342 & 21.584 & 21.127 & 21.326 \\
\hline $\mathrm{BaO}$ & 0.023 & 0.026 & 0.022 & 0.026 & 0.139 & 0.135 & 0.139 & 0.134 \\
\hline $\mathrm{CaO}$ & 2.365 & 2.399 & 2.340 & 2.369 & 2.415 & 2.439 & 2.391 & 2.410 \\
\hline $\mathrm{CdO}$ & 0.000 & 0.000 & 0.000 & 0.000 & 0.096 & 0.110 & 0.093 & 0.106 \\
\hline $\mathrm{Ce}_{2} \mathrm{O}_{3}$ & 0.025 & 0.028 & 0.024 & 0.027 & 0.024 & 0.028 & 0.024 & 0.027 \\
\hline $\mathrm{Cr}_{2} \mathrm{O}_{3}$ & 0.047 & 0.055 & 0.045 & 0.053 & 0.103 & 0.106 & 0.102 & 0.105 \\
\hline $\mathrm{CuO}$ & 0.017 & 0.020 & 0.016 & 0.019 & 0.027 & 0.029 & 0.026 & 0.028 \\
\hline $\mathrm{Fe}_{2} \mathrm{O}_{3}$ & 27.600 & 27.753 & 27.342 & 27.444 & 29.025 & 29.223 & 28.752 & 28.896 \\
\hline $\mathrm{Gd}_{2} \mathrm{O}_{3}$ & 0.000 & 0.000 & 0.000 & 0.000 & 0.022 & 0.022 & 0.022 & 0.022 \\
\hline $\mathrm{K}_{2} \mathrm{O}$ & 0.031 & 0.030 & 0.031 & 0.030 & 0.131 & 0.137 & 0.129 & 0.135 \\
\hline $\mathrm{La}_{2} \mathrm{O}_{3}$ & 0.017 & 0.020 & 0.017 & 0.019 & 0.015 & 0.018 & 0.015 & 0.017 \\
\hline $\mathrm{Li}_{2} \mathrm{O}$ & 0.000 & 0.000 & 0.000 & 0.000 & 0.013 & 0.015 & 0.013 & 0.014 \\
\hline $\mathrm{MgO}$ & 1.549 & 1.632 & 1.524 & 1.602 & 1.567 & 1.642 & 1.544 & 1.613 \\
\hline $\mathrm{MnO}$ & 5.850 & 5.867 & 5.799 & 5.805 & 5.992 & 5.985 & 5.943 & 5.926 \\
\hline $\mathrm{Na}_{2} \mathrm{O}$ & 26.491 & 25.786 & 27.204 & 26.641 & 22.875 & 22.288 & 23.596 & 23.152 \\
\hline $\mathrm{NiO}$ & 2.979 & 2.894 & 2.965 & 2.877 & 3.081 & 2.985 & 3.068 & 2.969 \\
\hline $\mathrm{P}_{2} \mathrm{O}_{5}$ & 0.002 & 0.002 & 0.002 & 0.002 & 0.326 & 0.367 & 0.318 & 0.357 \\
\hline $\mathrm{PbO}$ & 0.021 & 0.024 & 0.021 & 0.024 & 0.018 & 0.020 & 0.018 & 0.020 \\
\hline $\mathrm{PdO}$ & 0.000 & 0.000 & 0.000 & 0.000 & 0.001 & 0.001 & 0.001 & 0.001 \\
\hline $\mathrm{Pr}_{2} \mathrm{O}_{3}$ & 0.003 & 0.003 & 0.003 & 0.003 & 0.003 & 0.003 & 0.003 & 0.003 \\
\hline $\mathrm{PuO}_{2}$ & 0.000 & 0.000 & 0.000 & 0.000 & 0.007 & 0.007 & 0.007 & 0.007 \\
\hline $\mathrm{Rh}_{2} \mathrm{O}_{3}$ & 0.000 & 0.000 & 0.000 & 0.000 & 0.028 & 0.027 & 0.028 & 0.027 \\
\hline $\mathrm{RuO}_{2}$ & 0.006 & 0.006 & 0.006 & 0.006 & 0.142 & 0.137 & 0.142 & 0.136 \\
\hline $\mathrm{SO}_{4}{ }^{2-}$ & 0.606 & 0.628 & 0.599 & 0.619 & 0.740 & 0.757 & 0.732 & 0.748 \\
\hline $\mathrm{SiO}_{2}$ & 2.305 & 2.338 & 2.281 & 2.309 & 2.172 & 2.207 & 2.149 & 2.179 \\
\hline $\mathrm{SrO}$ & 0.002 & 0.002 & 0.002 & 0.002 & 0.068 & 0.066 & 0.068 & 0.066 \\
\hline $\mathrm{ThO}_{2}$ & 0.000 & 0.000 & 0.000 & 0.000 & 0.000 & 0.000 & 0.000 & 0.000 \\
\hline $\mathrm{TiO}_{2}$ & 1.311 & 1.313 & 1.310 & 1.312 & 1.307 & 1.309 & 1.307 & 1.309 \\
\hline $\mathrm{U}_{3} \mathrm{O}_{8}$ & 7.973 & 8.048 & 7.895 & 7.954 & 8.147 & 8.188 & 8.072 & 8.099 \\
\hline $\mathrm{ZnO}$ & 0.004 & 0.004 & 0.004 & 0.004 & 0.014 & 0.013 & 0.014 & 0.013 \\
\hline $\mathrm{ZrO}_{2}$ & 0.029 & 0.033 & 0.028 & 0.032 & 0.151 & 0.146 & 0.150 & 0.146 \\
\hline
\end{tabular}

\subsection{Assessments of Frit 418 with the Nominal SB5 Compositions}

The 16 potential SB5 compositions described in the previous section (referred to as nominal SB5 compositions) were combined with Frit 418 over a WL interval of 25 to $60 \%$ and evaluated against the DWPF Product Composition Control System (PCCS) Measurement Acceptability Region (MAR) criteria to identify WLs where acceptable glasses are predicted. ${ }^{3}$ The results of the Nominal Stage MAR assessment are given in Table 3-1. In general, the window of available WLs with Frit 418 is quite good, with all of the nominal compositions predicted to form acceptable glasses from 30 to 41\% WL (with several of the individual systems having even wider WL windows). Lower WLs are limited by the homogeneity constraint (Homg), which can be relaxed for the compositions that do not include the ARP stream. ${ }^{4}$ Upper WLs are limited by 
WSRC-STI-2008-00338

Revision 0

predictions of low viscosity (lowv), high liquidus temperature $\left(\mathrm{T}_{\mathrm{L}}\right)$, or nepheline crystallization (Neph).

Table 3-1. MAR Assessment Results for the Nominal SB5 Compositions with Frit 418.

\begin{tabular}{||c|c|c|c||}
\hline Sludge ID & $\begin{array}{c}\text { Acceptable } \\
\text { WLs (\%) }\end{array}$ & $\begin{array}{c}\text { Lower Limiting } \\
\text { Constraint(s) }\end{array}$ & $\begin{array}{c}\text { Upper Limiting } \\
\text { Constraint(s) }\end{array}$ \\
\hline BS-01 & $29-43$ & Homg & lowv \\
\hline BS-02 & $28-44$ & Homg & lowv, Neph \\
\hline BS-03 & $29-42$ & Homg & lowv \\
\hline BS-04 & $29-43$ & Homg & lowv \\
\hline BS-05 & $28-44$ & Homg & $\mathrm{T}_{\mathrm{L}}$ \\
\hline BS-06 & $27-43$ & Homg & $\mathrm{T}_{\mathrm{L}}$ \\
\hline BS-07 & $28-45$ & Homg & $\mathrm{T}_{\mathrm{L}}, \mathrm{Neph}$ \\
\hline BS-08 & $28-44$ & Homg & $\mathrm{T}_{\mathrm{L}}$ \\
\hline BS-09 & $30-42$ & Homg & lowv \\
\hline BS-10 & $29-43$ & Homg & lowv \\
\hline BS-11 & $30-41$ & Homg & lowv \\
\hline BS-12 & $30-42$ & Homg & lowv \\
\hline BS-13 & $29-46$ & Homg & $\mathrm{T}_{\mathrm{L}}$, lowv, Neph \\
\hline BS-14 & $29-45$ & Homg & $\mathrm{T}_{\mathrm{L}}$ \\
\hline BS-15 & $29-45$ & Homg & lowv, Neph \\
\hline BS-16 & $29-45$ & Homg & Neph \\
\hline
\end{tabular}

The results of the MAR assessment with the nominal SB5 compositions show that Frit 418 is robust to these variations for the SB5 composition, including differences between the LWO and SRNL projections, the addition of caustic, varying blends of Tank 40 and Tank 51, and the addition of the ARP stream. Frit 418 appears to be particularly robust to a range of $\mathrm{Na}_{2} \mathrm{O}$ concentrations for SB5. The WL windows over which the glasses are predicted to be acceptable are generally limited by process-related constraints (lowv and $T_{L}$ ). Five of the WL windows are limited by predictions of nepheline crystallization (which can impact durability of the glass). However, nepheline is only predicted to form at WLs that are significantly higher ( $>44 \% \mathrm{WL}$ ) than those likely to be targeted by DWPF.

\subsection{Variation Stage Assessment of Frit 418 Bounding Potential SB5 Compositions}

A Variation Stage assessment was next performed to further demonstrate the ability of Frit 418 to accommodate variation in the composition of SB5. The following strategy was developed to apply variation to the compositional region bounding the series of potential SB5 compositions. First, the minimum and maximum concentrations of each component across all 16 of the potential SB5 compositions were determined. Then, for each of the major components $\left(\mathrm{Al}_{2} \mathrm{O}_{3}, \mathrm{Fe}_{2} \mathrm{O}_{3}\right.$, $\mathrm{Na}_{2} \mathrm{O}$ and $\mathrm{U}_{3} \mathrm{O}_{8}$ ), the minimum concentration was reduced by $7.5 \%$ and the maximum concentration was increased by 7.5\%. For each of the minor components $(\mathrm{CaO}, \mathrm{MgO}, \mathrm{MnO}, \mathrm{NiO}$, $\mathrm{SiO}_{2}$ and $\mathrm{TiO}_{2}$ ), $0.5 \mathrm{wt} \%$ was deducted from the minimum concentration and $0.5 \mathrm{wt} \%$ was added to the maximum concentration. The remaining components were grouped into a category called 'Others'. The sum of the mean concentrations of each of the remaining components over the 16 potential SB5 compositions was taken as the concentration of Others. A variation of $+/-0.5 \mathrm{wt} \%$ was then applied to the concentration of Others. The resulting compositional space defined for the Variation Stage assessment is given in Table 4-1. 
WSRC-STI-2008-00338

Revision 0

Table 4-1. Concentration Ranges for Individual Components in the SB5 Composition as Defined for the Variation Stage Assessment.

\begin{tabular}{||c|c|c||}
\hline Oxide & $\begin{array}{c}\text { Minimum } \\
\text { (wt\%) }\end{array}$ & $\begin{array}{c}\text { Maximum } \\
\text { (wt\%) }\end{array}$ \\
\hline $\mathrm{Al}_{2} \mathrm{O}_{3}$ & 18.977 & 24.085 \\
\hline $\mathrm{CaO}$ & 1.840 & 3.016 \\
\hline $\mathrm{Fe}_{2} \mathrm{O}_{3}$ & 25.292 & 32.400 \\
\hline $\mathrm{MgO}$ & 1.024 & 2.223 \\
\hline $\mathrm{MnO}$ & 5.299 & 6.572 \\
\hline $\mathrm{Na}_{2} \mathrm{O}$ & 19.781 & 29.245 \\
\hline $\mathrm{NiO}^{2-}$ & 2.377 & 3.674 \\
\hline $\mathrm{SO}_{4}{ }^{2-}$ & 0.380 & 0.857 \\
\hline $\mathrm{SiO}_{2}$ & 1.649 & 2.924 \\
\hline $\mathrm{TiO}_{2}$ & 0.000 & 1.813 \\
\hline $\mathrm{U}_{3} \mathrm{O}_{8}$ & 7.302 & 9.088 \\
\hline $\mathrm{Others}^{2}$ & 0.284 & 1.284 \\
\hline
\end{tabular}

Table 4-1 provides the framework around which the Variation Stage assessment was conducted. A sludge composition is in the region defined in Table 4-1 if its concentration for each oxide is within the minimum and maximum interval for that oxide (e.g., the $\mathrm{Al}_{2} \mathrm{O}_{3}$ concentration in the sludge is between 18.98 and $24.09 \mathrm{wt} \%$ ) and the sum of the concentrations of all of the oxides in the sludge equals $100 \%$. Such a composition is a mixture of oxides at concentrations that correspond to one of the possible compositions for SB5 as defined by Table 4-1. Algorithms are available in statistical software packages ${ }^{\mathrm{a}}$ to generate the compositions that are the bounding "corner points" of the compositional region defined by Table 4-1. The bounding compositions generated by the software are called the extreme vertices (EVs) of the compositional region.

A total of 3920 SB5 EVs was generated to cover this compositional region. Each of the SB5 EVs was combined with Frit 418 over a WL interval of 25 to $60 \%$ and evaluated against the DWPF PCCS MAR criteria to determine whether the resulting glass is predicted to be acceptable. A select set of the Variation Stage MAR assessment results is shown in Table 4-2. For each WL, the number of acceptable and non-acceptable EVs is shown, along with the constraints limiting the non-acceptable EVs.

${ }^{\mathrm{a}} \mathrm{JMP}^{\mathrm{TM}}$, Ver. 6.0.3, SAS Institute Inc., Cary, NC (2005). 
WSRC-STI-2008-00338

Revision 0

Table 4-2. Portion of the Variation Stage MAR Assessment Results for SB5 with Frit 418.

\begin{tabular}{|c|c|c|c||}
\hline WL & $\begin{array}{c}\text { No. of } \\
\text { Acceptable EVs }\end{array}$ & $\begin{array}{c}\text { No. of } \\
\text { Non-Acceptable EVs }\end{array}$ & $\begin{array}{c}\text { Limiting } \\
\text { Constraint(s) }\end{array}$ \\
\hline 28 & 1833 & 2087 & Homg \\
\hline 29 & 2374 & 1546 & Homg \\
\hline 30 & 2674 & 1246 & Homg \\
\hline 31 & 2838 & 1082 & Homg \\
\hline 32 & 3174 & 746 & Homg \\
\hline 33 & 3560 & 360 & Homg \\
\hline 34 & 3904 & 16 & Homg \\
\hline 35 & 3920 & 0 & none \\
\hline 36 & 3920 & 0 & none \\
\hline 37 & 3920 & 0 & none \\
\hline 38 & 3902 & 18 & $\begin{array}{c}\text { lowv (11) } \\
T_{L}(7)\end{array}$ \\
\hline 39 & 3722 & 198 & $\begin{array}{c}\text { lowv (139) } \\
T_{L}(59)\end{array}$ \\
\hline \hline
\end{tabular}

All of the EVs produced acceptable glasses at WLs of 35 to 37\%. Access to lower WLs becomes limited by the homogeneity constraint (which can be relaxed for the sludges without ARP). Access to higher WLs becomes limited by process-related constraints (lowV and $\mathrm{T}_{\mathrm{L}}$ ) rather than durability-related constraints. As expected, the WL window within which all of the glasses are acceptable is smaller in the Variation Stage than in the Nominal Stage assessment. However, given the large variation applied to the potential SB5 composition and particularly to the $\mathrm{Na}_{2} \mathrm{O}$ concentration, the performance of Frit 418 is excellent. Assuming the homogeneity constraint can be relaxed for both sludge-only and coupled operations, ${ }^{\text {a }}$ all of the EVs could be processed over a $28-37 \%$ WL interval with only 18 of the 3920 EVs failing lowv or $\mathrm{T}_{\mathrm{L}}$ at $38 \% \mathrm{WL}$.

\subsection{Conclusions and Recommendations}

SRNL recommends that the DWPF utilize Frit 418 for initial processing of SB5. Nominal and Variation Stage assessments predict that Frit 418 will form an acceptable glass when combined with SB5 over a range of WLs, typically $30-41 \%$ based on the nominal projected SB5 compositions. Frit 418 has a relatively high degree of robustness with regard to variation in the projected SB5 composition, particularly when the $\mathrm{Na}_{2} \mathrm{O}$ concentration is varied. The acceptability (chemical durability) and model applicability of the Frit 418-SB5 system will be verified experimentally through a variability study, to be documented separately. Frit 418 has not been designed to provide an optimal melt rate with SB5, but is recommended for initial processing of SB5 until experimental testing to optimize a frit composition for melt rate can be completed.

\footnotetext{
a The opportunity to relax the homogeneity constraint during coupled operations (i.e., the addition of the ARP stream) will be explored during the SB5 variability study and documented separately.
} 
WSRC-STI-2008-00338

Revision 0

\subsection{References}

1. Culbertson, B. H., "Sludge Batch 5 Frit Optimization," U.S. Department of Energy Report HLW-DWPF-TTR-2007-0007, Revision 0, Washington Savannah River Company, Aiken, SC (2006).

2. Peeler, D. K., "Sludge Batch 5 Frit Optimization,” U.S. Department of Energy Report WSRCSTI-2006-00321, Washington Savannah River Company, Aiken, SC (2007).

3. Edwards, T. B., K. G. Brown and R. L. Postles, "SME Acceptability Determination for DWPF Process Control,” U.S. Department of Energy Report WSRC-TR-95-00364, Revision 5, Washington Savannah River Company, Aiken, SC (2006).

4. Herman, C. C., T. B. Edwards, D. R. Best, D. M. Marsh and R. J. Workman, "Reduction of Constraints: Phase 2 Experimental Assessment for Sludge-Only Processing,” U.S. Department of Energy Report WSRC-TR-2002-00482, Revision 0, Westinghouse Savannah River Company, Aiken, SC (2002). 


\section{Distribution:}

C.J. Bannochie, 773-42A

A.B. Barnes, 999-W

P.L. Bovan, 704-27S

J.M. Bricker, 704-27S

A.S. Choi, 773-42A

B.A. Davis, 704-27S

T.B. Edwards, 999-W

T.L. Fellinger, 704-26S

K.M. Fox, 999-W

J.M. Gillam, 766-H

J.C. Griffin, 773-A

B.A. Hamm, 766-H

C.C. Herman, 999-W
J.F. Iaukea, 704-30S

D.H. Miller, 999-W

T.A. Nance, 773-42A

R.T. McNew, 704-27S

J.D. Newell, 999-W

J.E. Occhipinti, 704-S

D.K. Peeler, 999-W

J.W. Ray, 704-S

H.B. Shah, 766-H

M.E. Stone, 999-W

J. Stuberfield, 766-H

A.L. Youchak, 999-W 